\title{
Eficácia e Tolerabilidade da Nimesulida Versus Celecoxib na Osteoartrite
}

\author{
Efficacy and Tolerability of Nimesulide Versus Celecoxib in Osteoarthritis
}

\author{
NilzIO AntonIo da SILVA ${ }^{1}$, LUIZ Roberto S. MARCZYK ${ }^{2}$
}

\section{RESUMO}

O objetivo do estudo foi comparar a eficácia e a tolerabilidade da nimesulida versus o celecoxib no tratamento da osteoartrite.

A casuística envolveu 57 pacientes com idade entre 40 e 80 anos, que foram randomizados em dois grupos, recebendo as medicações do estudo durante 30 dias de forma simples-cega na dosagem de um comprimido de 100mg de nimesulida duas vezes ao dia e uma cápsula de 100mg de celecoxib duas vezes ao dia. Após a inclusão no estudo na visita basal, foram realizadas três visitas com intervalo de dez dias entre elas.

Os aspectos analisados foram: dor em repouso, dor em movimento e dor noturna, através de uma escala analógica da dor, duração da rigidez matinal, capacidade funcional (HAQ), classe funcional ACR-1991 e o índice de gravidade para osteoartrite de joelhos em todas as visitas. Foi também avaliado o tempo para andar 15 metros naqueles pacientes com acometimento de joelhos ou quadril. A avaliação da eficácia e tolerabilidade foi realizada pelo investigador e pelo paciente nas três visitas após o início do tratamento. Os eventos adversos foram registrados durante todo o período do estudo.

Houve diminuição significativa e semelhante nas médias da escala para dor ao movimento e dor em repouso para ambos medicamentos em todas as visitas. Houve diminuição da dor noturna ao longo do tratamento no grupo celecoxib e a partir da visita 3 no grupo nimesulida, e ao final do estudo, as médias dos dois grupos foram semelhantes ( $p=0,152$ ).

As médias da duração da rigidez matinal diminuíram significativamente no grupo tratado com nimesulida durante todo o seguimento, e no grupo celecoxib a partir da visita 3, sendo

\section{SUMMARY}

The aim of the present study was to compare the efficacy and tolerability of nimesulide versus celecoxib in the treatment of osteoarthritis.

Fifty seven patients aged between 40 and 80 years old were randomly allocated in a single-blind fashion to one of two treatment groups, which consisted in a 30-day treatment with nimesulide (tablets) or celecoxib (capsules), $100 \mathrm{mg}$ twice a day of either one. After the baseline period, there were three visits with a 10-day interval between each.

At each visit, the severity of pain (at rest, movement and night), morning stiffness, the degree of functional impairment (HAQ), functional classification (ACR-1991) and severity index for knee osteoarthritis were evaluated. For those with osteoarthritis of the knee or hip, the time that was necessary to walk fifteen meters was measured. The efficacy and tolerability were assessed separately by physicians and patients at all visits except during the baseline visit. All adverse events were reported throughout the whole study period.

There was a significant and similar decrease in the averages of the pain scale at movement and rest for both groups at all visits. The nocturnal pain decreased throughout the treatment for the celecoxib group and at the third visit for the nimesulide group. At the end of the study period these averages were statistically similar $(p=0,152)$.

The mean duration of morning stiffness decreased significantly in the nimesulide group throughout the whole study, and began only from the third visit on for the celecoxib group, becoming statistically similar at the end $(p=0,993)$. The mean time to walk the fifteen
1. Professor Titular de Reumatologia da Faculdade de Medicina da Universidade Federal de Goiás. Chefe do Departamento de Clínica Médica e do Serviço de Reumatologia da FM/Hospital das Clínicas da Universidade Federal de Goiás.

2. Professor Titular de Ortopedia e Traumatologia da Faculdade de Medicina da Universidade Federal do Rio Grande do Sul. Chefe do Serviço de Ortopedia e Traumatologia do Hospital de Cínicas de Porto Alegre - RS.
1. Head Professor of Rheumatology - School of Medicine, Federal University of Goiás. Chief of Internal Medicine Department and Rheumathology Service SM/Clinics Hospital from Federal University of Goiás.

2. Head Professor of Orthopedics and Traumatology - School of Medicine, Federal University of Rio Grande do Sul. Chief of Orthopedy and Traumatology Service from Clinics Hospital of Porto Alegre-RS. 
semelhantes ao final do estudo ( $p=0,993$ ). O tempo médio para andar 15 metros diminuiu significativamente no grupo nimesulida na visita $4\left(p<0,001^{\star}\right)$, e todas as médias deste intervalo de tempo foram menores do que no grupo celecoxib a partir da segunda visita.

Houve diminuição significativa nas médias de capacidade funcional ( escala HAQ) no grupo nimesulida durante todo o período do estudo, enquanto que no grupo celecoxib, apenas na visita 4 , onde as médias foram semelhantes ( $p=0,517)$. No grupo nimesulida o índice de gravidade de Lequesne e Samson (1991) para osteoartrite de joelhos diminuiu significativamente a partir da visita 3, o que não ocorreu no grupo celecoxib. Os dois grupos tiveram evolução semelhante quanto à classificação funcional ACR-1991 durante o período do estudo.

Ambos grupos foram semelhantes na avaliação da eficácia e da tolerabilidade segundo o paciente, e da eficácia segundo o médico. Durante o período do estudo, $21 \%$ dos pacientes do grupo nimesulida e $25 \%$ do grupo celecoxib apresentaram eventos adversos.

Em conclusão, a nimesulida demonstrou eficácia e tolerabilidade semelhante ao celecoxib no tratamento da osteoartrite. A dor noturna diminuiu mais precocemente no grupo celecoxib; nos parâmetros rigidez matinal, capacidade funcional e o índice de gravidade para a osteoartrite de joelho constatou-se uma resposta mais rápida nos pacientes tratados com a nimesulida.

Palavras-chave: osteoartrite, nimesulida, celecoxib.

\section{INTRODUÇÃO}

A osteoartrite $(\mathrm{OA})$ é, dentre as artropatias, a mais comum, sendo universal e, quase sempre, levando a importante impacto social tanto para o paciente como para a sociedade como um todo. A OA acomete em geral indivíduos acima de 50 anos de idade, sendo as articulações dos joelhos e coxo-femurais as mais freqüentemente afetadas ${ }^{1}$.

Esta moléstia caracteriza-se pela dor, tumefação e rigidez articular, os quais refletem algum grau de sinovite e crepitação, indicativos de lesão cartilaginosa que progride com o tempo. Os aspectos radiológicos são a diminuição do espaço articular, o aumento da densidade óssea subcondral, alterações proliferativas marginais das articulações e formação de cisto no osso subcondral. A maioria dos indivíduos com OA são assintomáticos. Quando a moléstia é sintomática, dor ao movimento e rigidez matinais são as manifestações mais comuns ${ }^{1,2,3}$.

A OA apresenta uma etiologia complexa e não há, até o momento, drogas que curem a moléstia. Sendo assim, as modalidades terapêuticas que possam minimizar os sintomas dos pacientes são indicadas. Dentre essas modalidades terapêuticas as mais utilizadas são os analgésicos e os antiiflamatórios nãohormonais, os quais fazem parte do roteiro de tratamento da OA ( "Guidelines"), recomendados pelo Colégio Americano de Reumatologia- 2000 4,5. meters decreased significantly for the nimesulide group only at visit $4\left(p<0,001^{\star}\right)$, and all the means from the second visit on were lower than those for the celecoxib group.

There was a significant decrease in the means of functional impairment (HAQ scale) for the nimesulide group during the whole study period, while in the celecoxib group this decrease appeared on visit 4 , where the means became similar ( $p=$ 0,517). The severity index of The Lesquesne \& Samson's (1991) for osteoarthritis of the knee for the nimesulide group decreased significantly from the third visit on, what did not happen with the celecoxib group. Both groups developed similarly in the functional classification (ACR1991) throughout the whole study.

Both groups had a similar efficacy and tolerability when evaluated by patients and of efficacy, when evaluated by physicians. During the study period, $21 \%$ of the patients of nimesulide group and $25 \%$ of celecoxib group complained of adverse events.

In conclusion, nimesulide demonstrated efficacy and tolerability similar to celecoxib in the treatment of osteoarthritis. Pain during the night decreased earlier in the celecoxib group, while patients of the nimesulide group showed a quicker regression of the parameters morning stiffness, functional capability and the severity index.

Key-words: osteoarthritis, nimesulide, celecoxib

\section{INTRODUCTION}

Osteoarthritis (OA) is, among arthropaties, the commonest, being universal and, almost always, leading to an important social impact to patients and to the society as a whole. Usually OA appears in patients older than 50 years, being knee and hip the joints most frequently affected ${ }^{1}$.

This disease is characterized by pain, stiffness and articular rigidity, which reflect some degree of sinovitis and crepitation, indicating time related and progressive cartilagenous lesion with time. The radiological aspects are the decrease of articular space, the increase of subcondral osteal density, proliferative changes in the margin of articulations and formation of cists in the subcondral bone. The majority of patients with OA have no symptoms. When the disease is symptomatic, pain at movement and morning stiffness are the most frequent symptoms ${ }^{1,2,3}$.

The OA has a complex ethiology and there are, up to this moment, no drugs to cure the disease. Therefore, indicated are the therapeutic options that might minimize the symptoms. Among them the most currently used are the analgesics and non-hormonal antiinflamatory drugs, recommended by the American College of Rheumatology - 2000 (Guidelines) for the treatment of $O A^{4,5}$. 
A descoberta da ciclooxigenase 2 (Cox-2) coloca em evidência que a seletividade na inibição das prostaglandinas é a característica que separa os efeitos terapêuticos dos efeitos indesejáveis, particularmente os gastrointestinais. De fato, as evidências indicam que a inibição da Cox-2 é responsável pelo efeito antiinflamatório. Por outro lado, a inibição da enzima ciclooxigenase 1 (Cox-1) produz alteração do estado fisiológico gástrico. O dano à mucosa do estômago devido à presença reduzida das prostaglandinas gastroprotetoras pode ser uma conseqüência direta desta alteração ${ }^{6,7,8}$.

Além disso a Cox-1 está presente fisiologicamente na maioria dos tecidos. Ela induz a síntese das prostaglandinas responsáveis pela manutenção da integridade da microcirculação, regulação da divisão celular e produção de muco. A Cox-2, ao contrário, não é detectada na maioria dos tecidos sob condições fisiológicas normais. Sua produção é induzida nos locais de inflamação pelas citocinas e endotoxinas ${ }^{9,10}$. Atualmente, a inibição específica seletiva da Cox-2 é um dos objetivos da terapêutica para que se obtenha boa tolerabilidade gastrointestinal.

Há evidências que a nimesulida seja um AINH inibidor seletivo da Cox-2 ${ }^{11,12,13}$ e assim, útil no tratamento de patologias inflamatórias ${ }^{1,2,3}$, sendo bem tolerado pela mucosa gástrica ${ }^{14,15}$, 16,17. O alto índice terapêutico da nimesulida relatado em estudos prévios despertou o interesse em se avaliar este fármaco na osteoartrite, nas quais o tratamento sintomático da dor é uma das abordagens mais importantes 18, 19, 20 .

O celecoxib é um AINE com ação específica inibitória da Cox-2 poupando a Cox-1 porém, sem a propriedade de limitar a formação de radicais livres ${ }^{21}$.

A nimesulida possui inúmeros estudos clínicos nacionais e internacionais na área reumatológica 22, 23, 24, 25, somando um grande número de pacientes avaliados frente a outros compostos, porém, até o momento, não foram realizados estudos comparativos entre a nimesulida e os mais recentes coxibs, AINHs aceitos como inibidores específicos de Cox-2. Com tal justificativa, a presente investigação foi proposta para comparar a nimesulida com o celecoxib, testando a eficácia e a tolerabilidade de ambas na OA num período de 1 mês.

\section{CASUÍSTICA E MÉTODOS}

Este estudo multicêntrico, comparativo, prospectivo, simplescego, randomizado teve como objetivo primário avaliar a eficácia clínica da nimesulida versus o celecoxib no tratamento de pacientes portadores de osteoartrite primária das mãos, quadris e joelhos, segundo os critérios do Colégio Americano de Reumatologia (ACR) (Altmann et al., 1990). O objetivo secundário foi avaliar a tolerabilidade após 10, 20 e 30 dias de tratamento conforme julgamento dos investigadores e pacientes e através da freqüência dos eventos adversos relatados.
The discovery of ciclooxigenase 2 (Cox-2) stresses that the selectivity of prostaglandins inhibition is the characteristic which separates the therapeutic effects from indesirable effects, mainly the gastrointestinal ones. Actually, the evidences indicate that the inhibition of Cox-2 is the responsible for the antiinflammatory effect. Conversely, the inhibition of the enzyme ciclooxigenase 1 (Cox-1) brings alterations to the gastric physiologic status. The damage to the gastric mucosa due to the reduction of gastroprotective prostaglandins could be a direct consequence of the change ${ }^{6}$. 7,8 .

Besides that, Cox-1 is physiologically present in the majority of tissues. It induces the synthesis of prostaglandins responsible for the maintenance of integrity of microcirculation, regulation of cellular division and production of mucus. In contrary, Cox-2 is not detected in most tissues under normal physiologic conditions. It's production is induced by citokins and endotoxins in the location of inflammation 9, 10. Currently, the specific and selective inhibition of Cox-2 is one of the therapeutic objectives aiming good gastrointestinal tolerability.

There are evidences that nimesulide is a NSAID with selective inhibition of Cox-2 ${ }^{11,12,13}$ and as such, useful in the treatment of inflammatory pathologies ${ }^{1,2,3}$, well tolerated by gastric mucosa $14,15,16,17$. The high therapeutic index of nimesulide reported in previous studies brought the interest of studying this drug in $\mathrm{OA}$, where the symptomatic treatment of pain is one of the most important approaches 18, 19, 20.

Celecoxib is a NSAID with specific inhibitory action of Cox-2 saving the enzyme Cox-1, but not limiting the production of free radicals ${ }^{21}$.

In rheumatology, there is a number of national and international clinical studies with nimesulide $22,23,24,25$, adding up a great number of patients where this compound was evaluated comparatively to others, however, up to now, the are no studies comparing nimesulide to the most recent coxibs, NSAIDs accepted as specific inhibitors of Cox-2. For this reason, the present study was proposed to compare nimesulide to celecoxib, assessing the efficacy and tolerability of both drugs in a one month treatment of $\mathrm{OA}$.

\section{METHODS}

The primary aim of this multicenter, comparative, prospective, single-blind and randomized study was to evaluate the clinical efficacy of nimesulide versus celecoxib in the treatment of patients with primary osteoarthritis of hands, hip and knees, according to the criteria of the Americam College of Rheumathology (ACR) (Altmann et al., 1990). The secondary aim was to evaluate the tolerability after 10,20 and 30 days of treatment, as judged by investigators and patients and by the frequency of adverse events reported. 
Foram incluídos 57 pacientes de ambos os sexos, com idade entre 40 e 80 anos, recrutados em dois centros, sendo que 29 foram tratados com nimesulida e 28 com celecoxib. Antes de iniciar o estudo todos os pacientes foram esclarecidos sobre os aspectos do projeto , e concordando com o mesmo ,assinaram um consentimento informado, que minuciosamente, em linguagem acessível, detalhava todo o andamento e os procedimentos . O estudo foi aprovado pelos Comitês de Ética das duas instituições onde foi conduzido.

Outros critérios de inclusão foram: pacientes apresentando quadro clínico sintomático de pelo menos seis meses de duração antes da visita de seleção, classe funcional I e II do Critério funcional ACR - 1991, cooperativos e com boa condição mental para compreender os objetivos do estudo. Os pacientes não poderiam ter sido medicados com AINEs nos 7 dias, antiinflamatórios esteróides nos 30 dias, bem como injeções intra-articulares nos seis meses que antecederam a visita de seleção.

Foram considerados critérios de exclusão a presença de diabetes mellitus tipo II não-compensado, insuficiência cardíaca congestiva, hipertensão arterial com pressão diastólica acima de $100 \mathrm{mmHg}$, úlcera péptica ou gastrite ( atual ou no ano que antecedeu a visita de seleção), doença pulmonar, hepática, renal, hematológica ou metabólica grave, obesidade ( índice de massa corporal > 30), alcoolismo ou abuso de drogas, lesão do menisco identificada clinicamente ou por imagem, gravidez e lactação, asma, hipersensibilidade aos medicamentos do estudo, ao ácido acetil-salicílico e a outros fármacos antiinflamatórios não-esteroidais (AINEs) bem como pacientes que estivessem participando de outro estudo clínico.

Na visita inicial ( V1) , foi realizada a pontuação do escore da dor ao movimento em uma escala visual analógica de 10mm: 0 (ausência de dor ) a 10 ( dor intensa), onde os pacientes deveriam ter valores $\geq 3$ ( nas mãos, em pelo menos duas articulações). Os portadores de OA de joelhos deveriam apresentar osteófitos radiográficos nas margens da articulação tíbio-femural e fêmuropatelar, rigidez matinal igual ou inferior a 30 minutos e presença de crepitação aos movimentos articulares. Os portadores de OA de mãos também deveriam apresentar rigidez e entumescimento de pelo menos duas articulações e aumento do tecido duro em pelo menos duas articulações interfalangeanas. Os pacientes com OA nos quadris deveriam apresentar osteófitos radiográficos femorais ou acetabulares e estreitamento radiográfico do espaço articular.

$\mathrm{Na} \mathrm{V} 1$, os pacientes foram randomizados para receber, de modo simples-cego, a dose recomendada para OA pelos fabricantes destes fármacos, a saber: comprimidos de 100mg de nimesulida ou cápsulas de 100mg de celecoxib a cada 12 horas, por 30 dias. Três visitas de controle clínico foram realizadas em intervalos de dez dias ( V2, V3 e V4 respectivamente).

O peso, índice de massa corporal ( IMC), pressão arterial (PAS/ $P A D)$ e freqüência cardíaca ( FC) dos pacientes foram avaliados na V1 e V4.
Fifty seven male and female patients were included, with age between 40 and 80 years old, enrolled in two sites, being 29 treated with nimesulide and 28 with celecoxib. In the screening phase all patients received information about the project, and being agreeable to it, have signed a informed consent, which, in accessible language explained in details the timelines and procedures. The study was approved by the Ethics Committee of both institutions where it was conducted.

Other inclusion criteria were: patients with symptomatic osteoarthritis for at least six months before the screening visit, functional class I and II from Functional Criteria ACR - 1991, cooperative and with good mental condition to understand the objectives of the study. The patients could not have received NSAIDs during the last 7 days, antiinflamatory steroids during the last 30 days, and intraarticular injections during the last 6 months before the screening visit.

Exclusion criteria were the presence of uncontrolled diabetes mellitus type II, congestive cardiac failure, peptic ulcer or gastritis (current or during the year preceding the screening), pulmonar, hepatic, renal, haematologic ou severe metabolic disease, obesity (index of corporal mass > 30), alchoolism or drug abuse, menisc lesion identified clinically or by image, pregnancy or lactation, hypersensitivity to study drugs, to aspirin and to other antiinflamatory non-steroidal drugs (NSAIDs), and also patients participating to other clinical investigation.

During the initial visit (V1), pain at movement was scored using a visual analogic scale of $10 \mathrm{~mm}$ : 0 (absence of pain), 10 (severe pain), when patients should have scores $\geq 3$ (in hand at least in two joints). Patients with $O A$ of the knee should have radiographic osteophytosis marginal to tibio-femoral and femoropatellar articulation, morning stiffness of 30 or less minutes and presence of crepitation to articular movements. Those patients with $O A$ of the hands should also present rigidity and stiffness of at least two joints and increase of hard tissue of at least two interfalangeal joints. Patients with OA of the hip should present femoral or acetabular radiographic osteophitosis and radiographic narrowing of the articular space.

If elegible, patients were randomized during $V 1$ to receive, in a single-blind fashion, the dose for OA recommended by manufacturers of the following drugs: nimesulide tablets $100 \mathrm{mg}$ or celecoxib capsules $100 \mathrm{mg}$, twice daily, during 30 days. Three control visits were performed with a 10-day interval between each ( V2, V3 and V4 respectively).

Weight, index of corporal mass (ICM), systolic and diastolic blood pressure (SBP, DBP) and heart rate (HR) were recorded at $\mathrm{V} 1$ and $\mathrm{V} 4$. 
Em todas as visitas foram realizados as seguintes avaliações: escore da dor ao movimento, dor em repouso e dor noturna, tempo (em segundos) para andar 15 metros naqueles pacientes com OA de joelhos ou quadril, duração da rigidez matinal em minutos ao levantar, classificação funcional (ACR 1991), capacidade funcional $\mathrm{HAQ}$, índice de gravidade para OA (IG-OA) de joelhos de Lequesne e Samson, registro da terapia medicamentosa concomitante e dos eventos adversos.

Os diversos aspectos foram submetidos à análise estatística para a comparação entre os grupos. Foi utilizado o teste t-Student ou Mann-Whitney, (quando as variâncias entre os grupos eram diferentes) na comparação da idade, altura, peso, IMC, PAS/PAD, FC e escala de dor à movimentação, dor em repouso e dor noturna. Na comparação das variâncias foi utilizado o teste de Levene. O teste de associação pelo qui-quadrado, com correção de Yates foi utilizado para comparar as perdas e a ocorrência de eventos adversos. As comparações entre interações de grupo/visita foram feitas utilizando a correção de Tukey-HSD. Para avaliar as suposições de normalidade foi utilizado o teste de Kolmogorov-Smirnof e para avaliar a igualdade das variâncias foi utilizado o teste de Levene. Em todas as análises estatísticas foi utilizado o nível de significância de $5 \%{ }^{26,27}$.

\section{RESULTADOS}

A Tabela 1 descreve as características demográficas de cada grupo, bem como as médias e desvios-padrão iniciais das escalas de dor em movimento, dor em repouso e dor noturna.

Tabela 1. Médias e desvios padrão (DP) iniciais para idade, altura, peso, IMC, PAS, PAD, pulso e escalas de dor ao movimento, dor em repouso e dor noturna em cada grupo de tratamento.

\begin{tabular}{|c|c|c|c|}
\hline Variável & $\begin{array}{c}\text { NIMESULIDA } \\
\text { média (DP) }\end{array}$ & $\begin{array}{c}\text { CELECOXIB } \\
\text { média (DP) }\end{array}$ & $\mathbf{p}^{* *}$ \\
\hline Idade & $60,80(8,48)$ & $62,66(12,43)$ & $0,363^{\mathrm{m}}$ \\
\hline Altura & $1,60(0,090)$ & $1,58(0,077)$ & $0,471^{\mathrm{t}}$ \\
\hline Peso & $66,84(10,05)$ & $66,29(12,51)$ & $0,855^{\mathrm{l}}$ \\
\hline IMC & $26,03(2,83)$ & $26,21(3,07)$ & $0,812^{\mathrm{t}}$ \\
\hline PAS & $133,79(15,39)$ & $134,64(19,00)$ & $0,853^{\mathrm{t}}$ \\
\hline PAD* $^{*}$ & $83,97(9,67)$ & $82,57(7,14)$ & $0,539^{\mathrm{m}}$ \\
\hline Pulso & $77,31(8,46)$ & $74,74(8,26)$ & $0,256^{\mathrm{l}}$ \\
\hline Dor ao movimento & $7,45(1,72)$ & $7,07(1,65)$ & $0,404^{\mathrm{t}}$ \\
\hline Dor em repouso & $5,21(2,97)$ & $5,21(2,49)$ & $0,992^{\mathrm{l}}$ \\
\hline Dor noturna & $5,21(2,98)$ & $4,89(2,59)$ & $0,672^{\mathrm{l}}$ \\
\hline
\end{tabular}

*: excluido um paciente com valor ignorado

**p: nível descritivo $t$ : teste $t$-Student $M$ : teste de Mann-Whitney
In all visits were following assessments were performed: pain at movement, pain at rest and night pain scores, time (in seconds) to walk 15 meters in those patients with OA in the knee or hip, duration in minutes of morning stiffness, functional classification (ACR 1991), functional capacity $H A Q$, severity index of Lequesne and Samson (SI-OA) for OA in the knee, record of concomitant medication and of adverse events.

The several aspects underwent statistical analysis for comparison between groups. To compare age, height, weight, ICM, SBPIDBP, HR and scale of pain at movement, pain at rest, and night pain the $t$-Student or Mann-Whitney tests (when variance between groups was different) were used. To compare variances the Levene test was used. The association test by chi-square, with correction of Yates was used to compare losses and occurrence of adverse events. The comparisons between interactions of group/visit were done using the correction of Tukey-HSD. To evaluate the assumptions of normality the test of Kolmogorov-Smirnof was used and to evaluate similarity of variances the test of Levene. In all statistical analysis the significance level of $5 \%$ was adopted 26, 27.

\section{RESULTS}

Table 1 describes the demographic characteristics of each study group, and baseline mean and standard deviation of pain at movement, pain at rest, and night pain scores.

Table 1. Baseline mean and SD for age, height, weight, ICM, SBP, DBP, $H R$, pain at movement, pain at rest and night pain scores in each group of treatment.

\begin{tabular}{|c|c|c|c|}
\hline Parameter & $\begin{array}{c}\text { NIMESULIDE } \\
\text { mean (SD) }\end{array}$ & $\begin{array}{c}\text { CELECOXIB } \\
\text { mean (SD) }\end{array}$ & $p^{* *}$ \\
\hline Age & $60,80(8,48)$ & $62,66(12,43)$ & $0,363^{m}$ \\
\hline Height & $1,60(0,090)$ & $1,58(0,077)$ & $0,471^{t}$ \\
\hline Weight & $66,84(10,05)$ & $66,29(12,51)$ & $0,855^{i}$ \\
\hline ICM & $26,03(2,83)$ & $26,21(3,07)$ & $0,812^{i}$ \\
\hline SBP & $133,79(15,39)$ & $134,64(19,00)$ & $0,853^{t}$ \\
\hline$D B P^{*}$ & $83,97(9,67)$ & $82,57(7,14)$ & $0,539^{m}$ \\
\hline$H R^{*}$ & $77,31(8,46)$ & $74,74(8,26)$ & 0,256 \\
\hline Pain at movement & $7,45(1,72)$ & $7,07(1,65)$ & $0,404^{i}$ \\
\hline Pain at rest & $5,21(2,97)$ & $5,21(2,49)$ & $0,992^{t}$ \\
\hline Night pain & $5,21(2,98)$ & $4,89(2,59)$ & $0,672^{i}$ \\
\hline
\end{tabular}


Observou-se que não há diferenças estatisticamente significativas entre as médias iniciais da idade, peso, altura, IMC, pressão arterial, FC, escala de dor ao movimento, dor em repouso e dor noturna nos dois grupos de tratamento. Isso demonstra que os pacientes eram semelhantes, em relação a estes parâmetros, no início da terapia.

A Tabela 2 apresenta a análise em relação às variáveis qualitativas. Verifica-se que os dois grupos foram semelhantes na distribuição em relação ao sexo, etnia, classe ACR localização da OA e tratamento prévio da OA.

Tabela 2. Distribuição dos pacientes segundo sexo, etnia, classe ACR inicial , localização da osteoartrose e tratamento prévio para osteoartrose em cada grupo de tratamento.

\begin{tabular}{|c|c|c|c|c|}
\hline Variável & Categoria & $\begin{array}{l}\text { NIMESULIDA } \\
\text { No. (\%) }\end{array}$ & $\begin{array}{c}\text { CELECOXIB } \\
\text { No. (\%) }\end{array}$ & $\mathbf{p}^{*}$ \\
\hline \multirow[t]{2}{*}{ Sexo } & masculino & $3(10)$ & $4(14)$ & 0,960 \\
\hline & feminino & $26(90)$ & $24(86)$ & \\
\hline \multirow[t]{3}{*}{ Etnia } & branco & $21(72)$ & $21(75)$ & 0,684 \\
\hline & negro & $4(14)$ & $2(7)$ & \\
\hline & pardo & $4(14)$ & $5(18)$ & \\
\hline \multirow[t]{4}{*}{ ACR } & I & $5(17)$ & $6(21)$ & 0,917 \\
\hline & II & $21(73)$ & $19(68)$ & \\
\hline & III & $3(10)$ & $3(11)$ & \\
\hline & IV & $-(-)$ & $-(-)$ & \\
\hline \multirow{4}{*}{$\begin{array}{l}\text { Localização da } \\
\text { osteoartrite }\end{array}$} & mão & $7(24)$ & $8(29)$ & 0,245 \\
\hline & joelho & $18(62)$ & $20(71)$ & \\
\hline & quadril & $2(7)$ & $-(-)$ & \\
\hline & vários & $2(7)$ & $-(-)$ & \\
\hline \multirow{2}{*}{$\begin{array}{l}\text { Tratamento } \\
\text { prévio }\end{array}$} & não & $9(31)$ & $12(43)$ & 0,515 \\
\hline & $\operatorname{sim}$ & $20(69)$ & $16(57)$ & \\
\hline total & & $29(100)$ & $28(100)$ & \\
\hline
\end{tabular}

*p: nivel descritivo do teste de associação pelo qui-quadrado.

Quarenta e oito pacientes seguidos durante todo o período do estudo foram avaliados quanto à dor ao movimento. Dois pacientes do grupo nimesulida eram portadores de OA em mais de uma localização ( joelho/quadril e joelho/mão/quadril). Verifica-se que houve uma diminuição significativa destas médias ao longo do tratamento para ambos medicamentos, os quais foram semelhantes em todas as visitas ( Gráfico 1).
There were no statistically significant differences between the initial means for age, weight, height, ICM, blood pressure, HR, scale for pain at movement, pain at rest and night pain scores in both groups of treatment. This shows that both groups of patients were similar, considering these parameters, at the beginning of therapy.

Table 2 presents the analysis of the qualitative variables. Both groups had a similar distribution concerning gender, ethnia, ACR class, OA location and previous treatment of $O A$.

Table 2. Distribution of patients at baseline concerning gender, ethnia, class ACR, OA location and previous treatment for OA in each group of treatment.

\begin{tabular}{|c|c|c|c|c|}
\hline Variable & Category & $\begin{array}{c}\text { NIMESULIDE } \\
\text { No. (\%) }\end{array}$ & $\begin{array}{c}\text { CELECOXIB } \\
\text { No. }(\%)\end{array}$ & $p^{*}$ \\
\hline \multirow[t]{2}{*}{ Gender } & male & $3(10)$ & $4(14)$ & 0,960 \\
\hline & female & $26(90)$ & 24 (86) & \\
\hline \multirow[t]{3}{*}{ Ethnia } & white & 21 (72) & $21(75)$ & 0,684 \\
\hline & black & $4(14)$ & $2(7)$ & \\
\hline & mulato & 4 (14) & 5 (18) & \\
\hline \multirow[t]{4}{*}{$A C R$} & I & $5(17)$ & $6(21)$ & 0,917 \\
\hline & II & 21 (73) & $19(68)$ & \\
\hline & III & $3(10)$ & $3(11)$ & \\
\hline & IV & $-(-)$ & $-(-)$ & \\
\hline \multirow{4}{*}{$\begin{array}{l}\text { Location of } \\
\text { osteoarthritis }\end{array}$} & hand & 7 (24) & $8(29)$ & 0,245 \\
\hline & knee & $18(62)$ & $20(71)$ & \\
\hline & hip & $2(7)$ & $-(-)$ & \\
\hline & several & $2(7)$ & $-(-)$ & \\
\hline \multirow{2}{*}{$\begin{array}{l}\text { Previous } \\
\text { treatment }\end{array}$} & no & 9 (31) & $12(43)$ & 0,515 \\
\hline & yes & $20(69)$ & $16(57)$ & \\
\hline total & & $29(100)$ & $28(100)$ & \\
\hline
\end{tabular}

*p: descriptive level of association test by chi-square.

Forty eight patients followed up during the study period were evaluated with respect to pain to movement. Two patients of the nimesulide group had OA in more than one location (kneel hip and knee/hand/hip). A significant decrease of the means was observed with both drugs, which were similar in all visits (Graphic 1). 
Gráfico 1. Médias da escala visual analógica de avaliação da dor ao movimento, segundo visita e medicamento
Graphic 1. Means of visual analogic scale for evaluation of pain at movement, according to visit and drug.

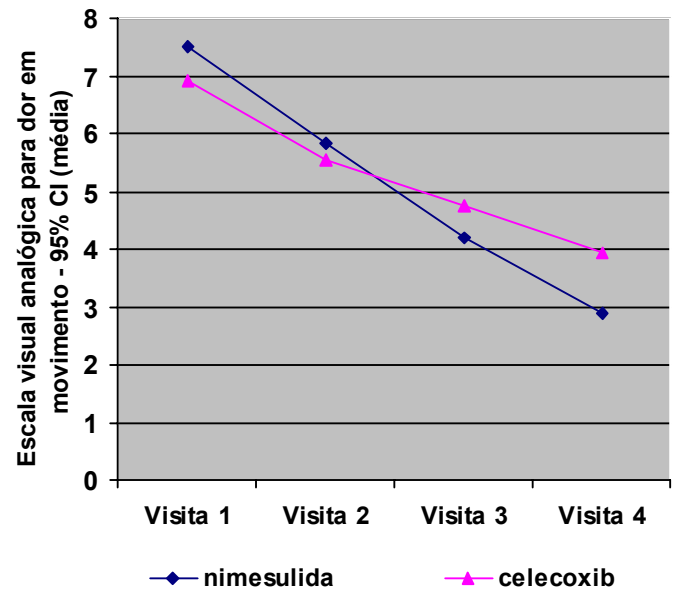

Verifica-se que houve uma diminuição significativa nas médias da escala de dor em repouso para ambos medicamentos, porém na V4 o grupo nimesulida apresentou menor média que o grupo tratado com celecoxib $\left(p=0,013^{\star}\right)$ (Gráfico 2).
There was a significant decrease in the means of pain at rest scores with both drugs, however, at V4 the nimesulide group presented alower mean than the group treated with celecoxib $\left(p=0,013^{*}\right)$ (Graphic 2).
Gráfico 2. Médias da escala visual analógica de avaliação da dor em repouso, segundo visita e medicamento.
Graphic 2. Means of visual analogic scale for evaluation of pain at rest, according to visit and drug.

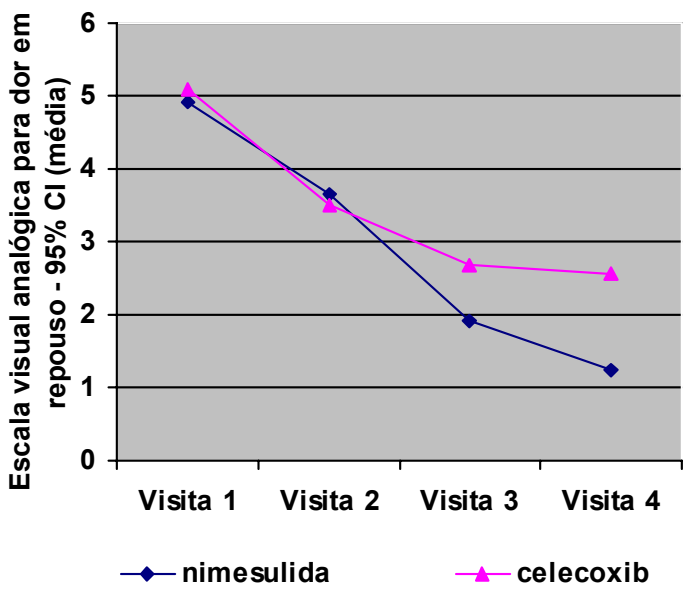

Observa-se que houve uma diminuição significativa nas médias da escala de dor noturna ao longo do tratamento no grupo celecoxib e a partir da V3 no grupo nimesulida. Ao final das quatro visitas, as médias dos dois grupos foram semelhantes ( $p=0,152)$. O Gráfico 3 apresenta estes resultados.
A significant decrease in night pain scores was observed during the treatment in the celecoxib group and with nimesulide from V3 on. At the end of four visits, the means of both groups were similar $(p=0,152)$. The Graphic 3 presents these results. 
Gráfico 3. Médias da escala visual analógica de avaliação da dor noturna, segundo visita e medicamento.
Graphic 3. Means of visual analogic scale for evaluation of night pain, according to visit and drug.

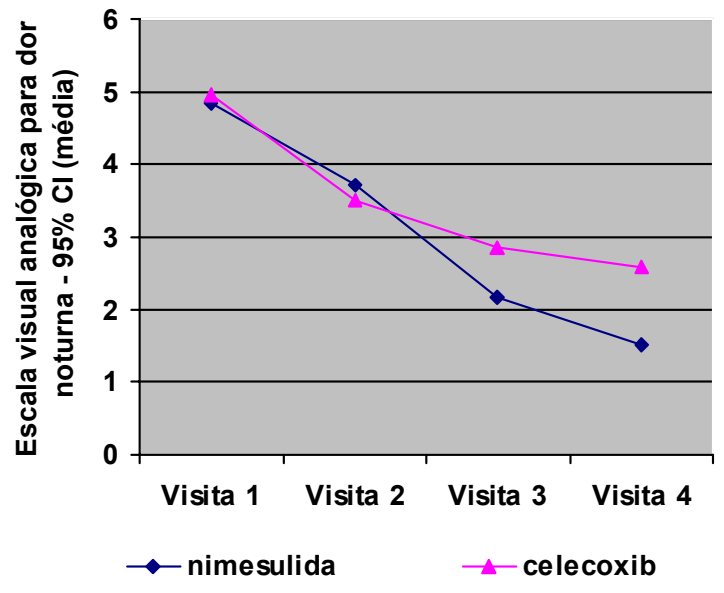

A duração da rigidez matinal ao levantar, mensurada em minutos, foi avaliada nos 48 pacientes que foram seguidos durante as quatro visitas. Verifica-se que houve uma diminuição significativa nestas médias no grupo tratado com a nimesulida durante todo o seguimento e no grupo celecoxib a partir da V3. Ao final do seguimento as médias dos grupos foram semelhantes $(p=0,093)$ (Gráfico 4).

Gráfico 4. Médias da duração aproximada da rigidez matinal ao levantar (em minutos), segundo visita e medicamento.
The duration of morning stiffness after waking up, recorded in minutes, was evaluated in 48 patients followed up during four visits. A significant decrease of the means in the group treated with nimesulide was observed in all visits and starting at V3 in the celecoxib group. At the end of the study period the means of both groups were similar $(p=0,093)$ (Graphic 4).

Graphic 4. Approximate mean duration of morning stiffness after waking up (in minutes), according to visit and drug.

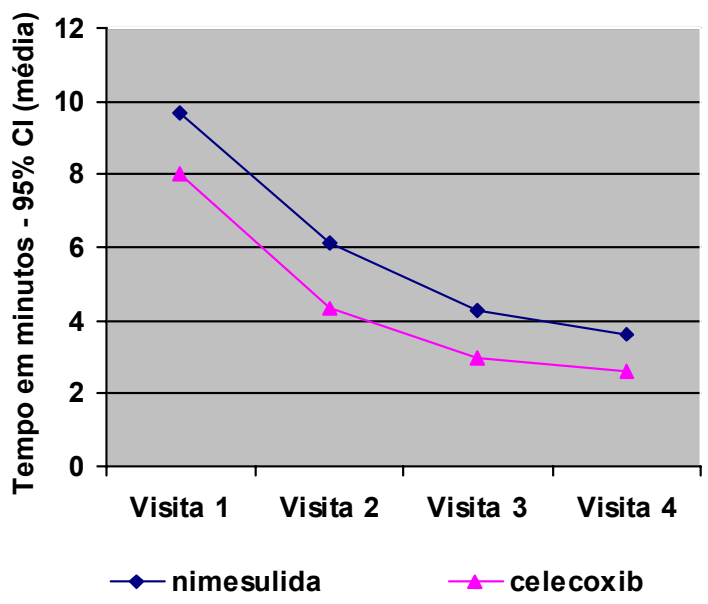

A análise do tempo médio que o paciente com OA de joelho e quadril leva para andar 15 metros, mensurado em segundos, considerou 37 pacientes com OA nestas localizações seguidos durante as quatro visitas. Os resultados mostram uma redução significativa nesta média apenas no grupo nimesulida, somente na V4. No grupo tratado com celecoxib não houve diferenças significativas entre as médias ao longo do seguimento. $\mathrm{Na}$ comparação entre os grupos, observa-se que os pacientes tratados com nimesulida tiveram médias menores que o grupo tratado com celecoxib a partir da V2. O Gráfico 5 descreve estes resultados.
The evaluation of the mean time the patient with knee and hip OA needs to walk 15 meters, recorded in seconds, was performed in 37 patients followed up for four visits. The results show a significant reduction of this mean only at V4 for the nimesulide group. There were no significant differences between the means during the the study period for the celecoxib group. Comparing both groups, patients treated with nimesulide had lower means than the group treated with celecoxib from V2 on. The Graphic 5 describes these results. 
Gráfico 5. Médias do tempo médio para o paciente com osteoartrite de joelho ou de quadril andar 15 metros (em segundos), segundo visita e medicamento.
Graphic 5. Means of average time for patients with OA of the knee or hip to walk 15 meters (in seconds), according to visit and drug.

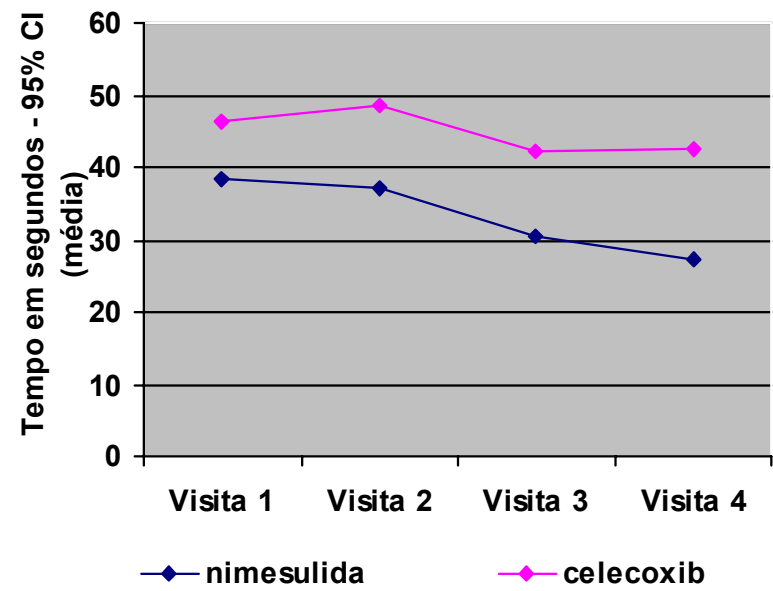

Verifica-se que houve uma diminuição significativa nas médias da escala HAQ de capacidade funcional no grupo tratado com nimesulida durante todo o seguimento, e no grupo tratado com celecoxib apenas na $4^{a}$. visita. Ao se compararem os dois grupos, verifica-se que, apesar de na visita inicial o grupo tratado com celecoxib ter média menor do que o grupo nimesulida $\left(p<0,001^{\star}\right)$, na V2 não houve diferença entre as médias ( $p=1,000)$, na V3 a média do grupo tratado com nimesulida foi menor do que a média do grupo tratado com celecoxib $\left(p=0,025^{\star}\right)$ e, na $\vee 4$, as médias voltaram a ser semelhantes $(p=0,517)$. O Gráfico 6 apresenta estes resultados.

There was a significant decrease in the means of functional capacity scale HAQ in the group treated with nimesulide during the study period, and in the group treated with celecoxib only at $\checkmark 4$. When both groups are compared, it was observed that, in spite of the celecoxib group mean, lower than that for nimesulide group $\left(p<0,001^{\star}\right)$, at $V 2$ there were no differences between the means $(p=1,000)$, at $V 3$ the nimesulide group mean was lower than that for celecoxib group ( $p=0,025^{*}$ ) and, at $V 4$, the means again were similar $(p=0,517)$. The Graphic 6 shows these results.

Gráfico 6. Médias da escala $H A Q$ de capacidade, segundo visita e medicamento.

Graphic 6. Means of HAQ scale for capacity, according to visit and drug.

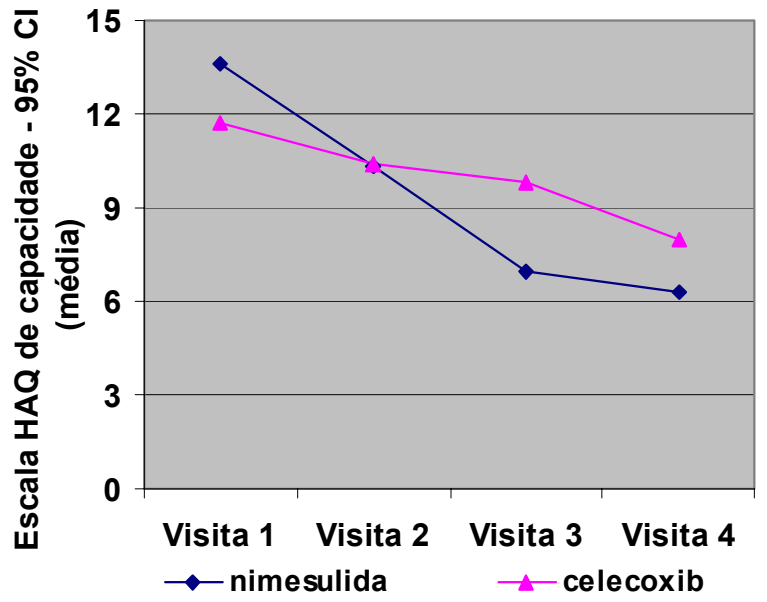

Houve uma diminuição significativa no IG-OA no grupo tratado com nimesulida a partir da $\mathrm{V} 3$, porém, no grupo tratado com celecoxib esta diminuição não ocorreu. A partir da V3 as médias do IG-OA do grupo tratado com nimesulida foram sempre menores às do grupo celecoxib ( $p<0,001$ * para V3 e V4) (Gráfico 7).
There was a significant reduction of SI-OA in the group treated with nimesulide from $\mathrm{V} 3$, however, in the group treated with celecoxib this reduction did not occur. The means of SI-OA in the group treated with nimesulide were always lower than those of the group celecoxib from V3 on. ( $p<0,001$ * for V3 and V4) (Graphic 7). 
Gráfico 7. Médias do índice de gravidade OA de joelhos, segundo visita e medicamento.
Graphic 7. Means of severity index for knee OA, according to visit and drug.

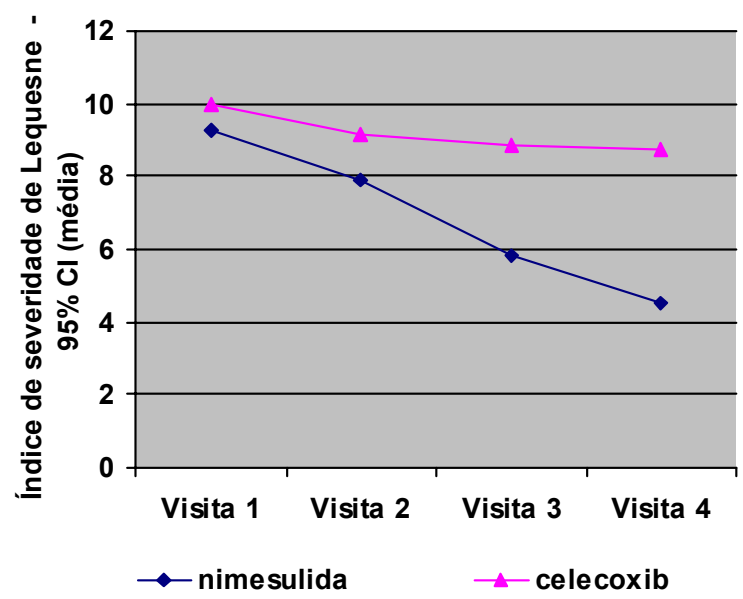

Os dois grupos foram semelhantes ao longo de todo o seguimento ( $p=0,796, p=0,496$ e $p=0,496$ respectivamente na $\mathrm{V} 2$, V3 e V4) quanto à classificação funcional ACR-1991.

No decorrer do estudo, houve a perda de seguimento de 9 pacientes, sendo 3 do grupo nimesulida e 6 do grupo celecoxib, não havendo diferença estatisticamente significativa entre os grupos $(p=0,433)$. Em um caso houve violação do protocolo e um caso de abandono, ambos do grupo celecoxib. Os demais pacientes (23\%) saíram pela ocorrência de evento adverso, onde 21\% eram do grupo nimesulida e $25 \%$ do grupo celecoxib. A análise da ocorrência dos eventos adversos está descrita na Tabela 3. Não houve associação estatisticamente significativa entre a ocorrência do evento adverso e medicamento $(p=0,943)$.

Tabela 3. Distribuição dos relatos de eventos adversos.

\begin{tabular}{|lcc|}
\hline \multicolumn{1}{c}{ Evento Relatado } & nimesulida & celecoxib \\
\hline Diarréia & $1(3,3 \%)$ & 0 \\
\hline Epigastralgia & $2(6,7 \%)$ & $2(6,7 \%)$ \\
\hline Náusea & $1(3,3 \%)$ & $2(6,7 \%)$ \\
\hline Vômito & 0 & $1(3,3 \%)$ \\
\hline Dor abdominal & $1(3,3 \%)$ & $1(3,3 \%)$ \\
\hline Pirose & $2(6,7 \%)$ & 0 \\
\hline Sensação de inchaço em abdômen & $1(3,3 \%)$ & 0 \\
\hline Dispnéia & 0 & $1(3,3 \%)$ \\
\hline Tontura & $2(6,7 \%)$ & 0 \\
\hline Palpitação & 0 & $2(6,7 \%)$ \\
\hline Agitação & $1(3,3 \%)$ & 0 \\
\hline Mal estar & $1(3,3 \%)$ & $3(10,0 \%)$ \\
\hline Prurido nas mãos & 0 & $1(3,3 \%)$ \\
\hline Edema labial e palpebral & 0 & $1(3,3 \%)$ \\
\hline Edema dos MMII & $1(3,3 \%)$ & $2(6,7 \%)$ \\
\hline Edema em mamas & 0 & $1(3,3 \%)$ \\
\hline & & \\
\hline Subtotal dos relatos & $13(43,3 \%)$ & $17(56,7 \%)$ \\
\hline Total dos relatos & $30(100 \%)$ & \\
\hline
\end{tabular}

Both groups were similar during the study period $(p=0,796$, $p=0,496$ e $p=0,496$ respectively for V2, V3 and V4) concerning functional classification ACR-1991.

Along the study, 9 patients lost follow up, 3 from the nimesulide group and 6 from the celecoxib group, without statistically significant difference between groups ( $p=0,433)$. In one case there was a protoco/ violation and one case of withdrawal, both in the celecoxib group. The other patients (23\%) stopped medication due to adverse events, $21 \%$ from the nimesulide group and $25 \%$ from the celecoxib group. The analysis of occurrence of adverse events is described in Table 3. There was no statistically significant association between occurrence of adverse events and drug ( $p=0,943)$.

Table 3. Distribution of reports of adverse events.

\begin{tabular}{|lcc|}
\hline \multicolumn{1}{c}{ Event Reported } & nimesulide & celecoxib \\
\hline Diarrhea & $1(3,3 \%)$ & 0 \\
\hline Epigastralgia & $2(6,7 \%)$ & $2(6,7 \%)$ \\
\hline Nausea & $1(3,3 \%)$ & $2(6,7 \%)$ \\
\hline Vomiting & 0 & $1(3,3 \%)$ \\
\hline Abdominal pain & $1(3,3 \%)$ & $1(3,3 \%)$ \\
\hline Heartburn & $2(6,7 \%)$ & 0 \\
\hline Abdominal plenitude & $1(3,3 \%)$ & 0 \\
\hline Dyspnea & 0 & $1(3,3 \%)$ \\
\hline Dizziness & $2(6,7 \%)$ & 0 \\
\hline Palpitation & 0 & $2(6,7 \%)$ \\
\hline Restlessness & $1(3,3 \%)$ & 0 \\
\hline Malaise & $1(3,3 \%)$ & $3(10,0 \%)$ \\
\hline Hands itching & 0 & $1(3,3 \%)$ \\
\hline Labial and palpebral & 0 & $1(3,3 \%)$ \\
edema & & $2(6,7 \%)$ \\
\hline Leg edema & $1(3,3 \%)$ & $1(3,3 \%)$ \\
\hline Breasts edema & 0 & \\
\hline & & $17(56,7 \%)$ \\
\hline Subtotal of reports & $13(43,3 \%)$ & 10 \\
\hline Total of reports & $30(100 \%)$ & \\
\hline
\end{tabular}


A avaliação da eficácia do tratamento segundo o paciente demonstrou que os dois grupos foram semelhantes (visita 2: $p=$ 0,609 , visita 3: $p=0,315$ e visita $4: p=0,171$ ), o mesmo ocorrendo quanto à tolerabilidade segundo o paciente (visita $2: p=1,000$, visita 3: $p=0,546$ e visita 4: $p=1,000)$, e à eficácia do tratamento segundo o médico (visita 2: $p=0,809$, visita 3: $p=0,490$ e visita 4: $p=0,078$ ).

Observou-se poucas mudanças no uso de terapia concomitante para os dois grupos de tratamento durante todo o seguimento, sendo os dois grupos semelhantes em todas as visitas (visita 1: $p=0,860$ visita 2: $p=0,860$; visita 3: $p=1,000$ e visita 4: $p=0,881$ ).

Não houve alteração nas médias do peso, IMC, FC, pressão arterial sistólica e diastólica no decorrer do estudo.

\section{DISCUSSÃo}

Este é o primeiro estudo clínico comparativo da nimesulida com um inibidor específico de Cox-2. Os resultados obtidos em nosso estudo demonstram que a nimesulida e o celecoxib são eficazes e bem tolerados no tratamento da osteoartrite.

Nossas observações estão de acordo com estudos prévios em que as drogas estudadas foram comparadas com outros fármacos AINEs, como o naproxeno, piroxicam e o cetoprofeno com relação à eficácia na $\mathrm{OA}{ }^{20,22,23,24}$. Nestes estudos, a nimesulida demonstrou controle rápido e sustentado da sintomatologia, com eficácia comparável ao naproxeno e ao piroxicam ${ }^{16}$. Da mesma forma, o celecoxib demonstrou ser tão eficaz quanto o naproxeno no tratamento da $\mathrm{OA}{ }^{21,28}$

Nossos resultados demonstram que a evolução da dor em movimento e em repouso ocorreu de forma semelhante nos dois grupos de tratamento, porém a diminuição da dor noturna foi constante ao longo do tratamento no grupo celecoxib, apresentando resultados semelhantes na V3 e V4 para ambas as drogas.

Em nosso estudo, observamos uma discreta tendência a resultados mais positivos no grupo nimesulida em alguns parâmetros estudados: a duração da rigidez matinal, embora semelhante entre as duas drogas ao final do estudo, apresentou diminuição significativa no grupo nimesulida durante todo o período do estudo, enquanto que no grupo celecoxib, apenas na $\mathrm{V} 3$ este dado foi constatado.

Com relação ao tempo médio para andar 15 metros, o grupo celecoxib não apresentou diminuição significativa durante todo o período do estudo. Já as médias de tempo do grupo nimesulida foram menores a partir do décimo dia de tratamento ( V2).

Os pacientes do grupo nimesulida apresentaram diminuição significativa nas médias do Índice de gravidade de Lequesne e Samson para OA de joelho desde a V3, e os do grupo celecoxib não apresentaram esta diminuição.
The efficacy evaluation assessed by patients showed that both groups were similar (visit 2: $p=0,609$, visit 3: $p=0,315$ and visit $4: p=0,171$ ), and the same occurred concerning tolerability (visit $2: p=1,000$, visit $3: p=0,546$ e visit $4: p=1,000$ ), and efficacy assessed by doctors (visit 2: $p=0,809$, visit 3: $p=0,490$ and visit $4: p=0,078$ ).

During the follow up period few changes of concomitant medication were reported in both groups of treatment, being both groups similar in all visits (visit $1: p=0,860$; visit $2: p=0,860$; visit 3: $p=1,000$ and visit $4: p=0,881)$.

During the study period there were no changes in the means of weight, ICM, HR, SBP/SBP.

\section{DISCUSSION}

This is the first comparative clinical study of nimesulide with a specific inhibitor of Cox-2. The results from our study show that nimesulide and celecoxib are efficacious and well tolerated in the treatment of osteoarthritis.

Our observations are similar to previous studies where the study drugs were compared to other NSAIDs, like naproxen, piroxicam and cetoprofen with respect to efficacy in the treatment of $O A{ }^{20,22,23,24 . ~ I n ~ t h e s e ~ s t u d i e s, ~ n i m e s u l i d e ~}$ demonstrated rapid and sustained control of symptomatology, with comparable efficacy to naproxen and piroxicam ${ }^{16}$. Similarly, celecoxib demonstrated being as efficacious as naproxen in the treatment of $O A^{21,28 .}$

Our results show that the decrease of pain at movement and pain at rest was similar in both treatment groups, however, the decrease of night pain was constant during treatment in the celecoxib group, but with similar results at V3 and V4 for both drugs.

In our study, we observed a light trend to more positive results for some parameters in nimesulide group: duration of morning stiffness, although similar between both drugs at the end of the study, had a significant reduction in nimesulide group during the whole study period, while in the celecoxib group, only at V3 this was observed.

Concerning the mean time to walk 15 meters, the celecoxib group did not show significant reduction during the entire study period, while the time means of the nimesulide group were lower from the tenth day of treatment (V2).

Patients of the nimesulide group had a significant decrease of means of the Severity Index of Lequesne and Samson for OA in the knee since V3, and those from the celecoxib group did not show this decrease. 
Também as médias da capacidade funcional HAQ evoluíram com diminuição significativa e constante ao longo do estudo no grupo nimesulida, sendo semelhantes nos dois grupos ao final do estudo.

Possivelmente estes resultados podem ser compreendidos pela ação inibitória que a nimesulida exerce sobre a síntese da metaloprotease, estudada por Pelletier, o qual demonstrou que, em doses terapêuticas, a nimesulida inibe a degradação da cartilagem osteoartrítica humana. Neste estudo, tanto o naproxeno como a nimesulida demonstraram propriedades terapêuticas interessantes com relação à fisiopatologia da $\mathrm{OA}$, como a diminuição dose / tempo-dependente da síntese da uroquinase e da interleucina6, enquanto estimulou a síntese do inibidor da ativação do plasminogênio ${ }^{24}$.

Com relação à tolerabilidade, os resultados deste estudo demonstram que o perfil de tolerabilidade da nimesulida é superponível ao do celecoxib, uma vez que a freqüência dos eventos adversos foi semelhante nos dois grupos de tratamento. A maioria dos eventos foi de caráter leve e transitório em ambos os grupos, sendo que no grupo celecoxib houve um caso de gastrite erosiva diagnosticada através de endoscopia digestiva.

A prevalência dos eventos adversos nesta população estudada poderia estar relacionada com a idade ( média 60,8 anos no grupo nimesulida e 62,6 no grupo celecoxib), uma vez que os idosos apresentam alterações freqüentes no perfil farmacocinético dos medicamentos administrados ${ }^{20}$.

Inúmeros estudos clínicos nacionais e internacionais, aliado ao grande número de pacientes estudados em estudos de pós-marketing que avaliaram a tolerabilidade da nimesulida demonstram um perfil de segurança superior aos AINEs clássicos no tratamento de afecções inflamatórias onde a dor é uma componente importante 3, 4, 10-20, 22-25, 29.

A freqüência de eventos adversos do grupo celecoxib foi maior do que os índices relatados na literatura ${ }^{21,28,30-36}$, havendo um caso de gastrite erosiva.

Em conclusão, nossos achados demonstram que a nimesulida e o celecoxib são semelhantes quanto à eficácia e tolerabilidade no tratamento da OA.

Embora haja suporte teórico e demonstração em outros estudos que os COXIBS tenham melhor tolerabilidade que os $\mathrm{AINH}$ não pertencentes a essa família de fármacos, aqui ficou demonstrado, num estudo de curta duração, que tal vantagem não ocorre em pacientes com OA primária, quando se comparou a nimesulida com o celecoxib.
Also the means of functional capacity $H A Q$ progressed with significant and constant reduction during the study in the nimesulide group, being similar in both groups at the end of the study.

Possibly these results can be understood by the inhibitory action of nimesulide over the synthesis of metaloproteasis, studied by Pelletier, who demonstrated that, in therapeutic doses, nimesulide inhibits the degradation of the human osteoarthritic cartilage. In this study, not only naproxen but also nimesulide have demonstrated interesting therapeutic properties related to the physiopathology of $O A$, as the decrease of time dependent synthesis of uroquinase and interleucin-6, while stimulating the synthesis of the inhibitor of activation of plasminogen ${ }^{24}$.

Concerning tolerability, the results of this study have shown that the profile of tolerability of nimesulide is similar to that of celecoxib, with similar frequency of adverse events in both treatment groups. The majority of the events was mild and transitory in both groups, with one case of erosive gastritis in one patient of the celecoxib group, endoscopically diagnosed.

The prevalence of adverse events in the studied population could be related to age (average of 60,8 years old in nimesulide group and 62,6 in group celecoxib), considering that elderly patients present frequent alterations of the pharmacokinetic profile of the administered drugs ${ }^{20}$.

Countless national and international clinical studies, besides the great number of patients studied in pos-marketing studies that evaluated the tolerability of nimesulide, demonstrate a safety profile superior to that of classical NSAIDs in the treatment of inflammatory diseases where pain is an important component 3, 4, 10-20, 22-25, 29 .

The frequency of adverse events observed in the celecoxib group was higher than what is reported in literature 21, 28, 30-36, with one case of erosive gastritis.

Concluding, our findings demonstrate that nimesulide and celecoxib are similar with respect to efficacy and tolerability in the treatment of $O A$.

Although there is theoretical support, and it has been demonstrated in other studies that COXIBS have better tolerability than NSAIDs not pertaining to this family of drugs, it was here demonstrated, in a short duration study, that such advantage did not occur in patients with primary $A O$, when nimesulide was compared to celecoxib. 


\section{REFERÊNCIAS}

1. Manek NJ, Lane NE. Osteoarthritis: Current Concepts in Diagnosis and Management. American Family Physician 2000; 61 (6): 1795-1804.

2. Hochberg MC, Altman RD, Brandt KD, et al. Guidelines for medical management of osteoarthritis. Arth Rhem 1995; 38: 1535-40.

3. Estudo Multicêntrico do Nimesulide em afeções traumato-ortopédicas. Arqu Bras Med 1991; 65(6): 643-646.

4. Dreiser RL, Riebenfeld D. A double-blind study of the efficacy of Nimesulide in the treatment of ankle sprain in comparison with placebo. Drugs 1993; 46 (suppl 1): 183-186.

5. American College of Rheumatology Subcommittee on Osteoarthritis Guidelines. "Recommendations for the medical management of osteoarthritis of the hip and knee". Arthritis Rheum 43 (9): 1905-1915, 2000.

6. Aslanian R, Carruthers NI, Kaminski J. Cyclooxygenase-2: a novel target for therapeutic intervention. Exp Opin Invest Drugs 1994; 3(12): 1323-1325.

7. Hayllar J. NSAIDs, COX-2 inhibitors, and the gut. Lancet 1995; 346: 521-522.

8. Taniguchi Y, Ikesue A, Yokoyama K, et al. Selective inhibition by nimesulide, a novel nonsteroidal anti-inflamatory drug, with prostaglandin endoperoxidase synthase-2 activity in-vitro. Pharmaceutical Sciences 1995; 1: 173-175.

9. Vane JR, Botting RM. New insights into the mode of action of antiinflamatory drugs. Inflamm Res 1995; 44: 1-10.

10. Tavares IA, Bishai PM, Benett A. Activity of nimesulide on constitutive and inducible cyclooxygenases. Arzneimittel Forschung / Drug Res 1995; 45-II(10): 1-3.

11. Vago T, Bevilacqua M, Norbiato G. Effects of nimesulide action time dependence on selectivity towards prostagladin $\mathrm{G} / \mathrm{H}$ synthase/ cyclooxygenase activity. Arzneimittel Forschung / Drug Res 1995; 45-II(10): 4-6

12. Dallegri F, Ottonello L, Bevilacqua M. Possible modes of action of nimesulide in controlling neutrophilic inflamation. Arzneimittel Forschung / Drug Res 1995; 45-II (10): 22-24.

13. Bevilacqua M, Magni E. Recent Contributions to Knowledge of the Mechanism of Action of Nimesulide. Drugs 1993; 46(suppl 1): 4047.

14. Cipollini F, Mecozzi V, Altilia F. Endoscopic assessment of the effect of nimesulide in the gastric mucosa: comparison with indomethacin Current Therapeutic Research 1989; 45: 1042-1048.

15. Marini V, Spotti D. Gastric Tolerability of Nimesulide. Drugs 1993; 46 (suppl 1): 249-252.

16. Dreiser RL and Benevelli DC. Long term tolerability profile of nimesulide in the treatment of osteoarthritis. Drugs 1993; 46 ( Suppl.1): 270274.

17. Rabasseda $X$. Safety profile of nimesulide: ten years of clinical experience. Drugs of today 1997; 33 ( Suppl.1):1-10.

18. Quattrini M, Paladin S. A Double-blind Study Comparing Nimesulide with Naproxen in the Treatment of Osteoarthritis of Hip. Clin Drug Invest 1995; 10 (3): 139-146.

19. Bourgeois $P$, Dreiser RL, Lequesne MG, Macciocchi A, Monti T Multicentre Double-blind study to define the most favourable dose of nimesulide in terms of efficacy / Safety ratio in the treatment of osteoarthritis. European Journal of Rheumatology and Inflammation 1994; 14 (2): 39-50.

20. Fossaluzza V, Montagnani G. Efficacy and tolerability of nimesulide in elderly patients with osteoarthritis: double-blind trial versus naproxen. The Journal of International Medical Research 1989;17: 295-303.

21. Clemett $D$ and Goa KL. Celecoxib A Review of its use in osteoarthritis, rheumatoid arthritis and acute pain. Drugs 2000; Apr; 59 (4): 957-
980.

22. Dreiser RL, Riebenfeld D. Nimesulide in the treatment of osteoarthritis. Drugs 1993;46 ( Suppl. 1): 191-195.

23. Pelletier J-P, Martel-Pelletier J. Effects of nimesulide and naproxen on the degradation and metalloprotease synthesis of human osteoarthritic cartilage. Drugs 1993; 46 ( Suppl. 1): 34-39.

24. Pelletier JP, Mineau F, Fernandes J, et al. Two NSAIDs, nimesulide and naproxen, can reduce the synthesis of urokinase and IL-6 while increasing PAI-1 in human OA synovial fibroblasts. Clinical and Experimental Rheumatology 1997; 15: 393-398.

25. Brito AS, et al. Estudo Multicêntrico do nimesulida na Reumatologia. Arquivos Brasileiros de Medicina 1992; 66 (4): 363-367.

26. Ingelfinger JA, Mosteller F, Thibodeau LA, et al. Biostatistics in Clinical Medicine. Second Edition, New York: Macmillan Publishing Co; Incontinência; 1987.

27. Neter J; Kutner MH, Nachtsheim CJ, Wasserman W. Applied Linear Statistical Models 1996; $4^{\text {th }}$ edition, Irwin, Chicago.

28. Goldenberg MM. Celecoxib, a selective cyclooxigenase-2 inhibitor for the treament of rheumatoid arthritis and osteoarthritis. Clinical Therapeutics 1999; 21 (9): 1497-1513.

29. Pochobradsky MG, Mele G, Beretta A, Montagnani G. Post-Marketing Survey of nimesulide in the short-term treatment of osteoarthritis. Drugs Exptl Clin Res 1991; XVII (3): 197-204.

30. Simon LS, Lanza FL, Lipsky PE et al. Preliminary Study of the Safety and Efficacy of SC-58635, a novel cyclooxygenase 2 inhibitor. Arthritis \& Rheumatism 1998; 41 (9): 1591-1602.

31. Marshall KW. Practical Implications of Cyclooxygenase 2 - specific inhibitors in orthopedics. American Journal of Orthopedics (supplement) 1999; 28 (35): 19-21.

32. Boyce $E G$ and Breen GA. Celecoxib: A COX-2 inhibitor for the treatment of osteoarthritis and rheumatoid arthritis. Formulary 1999; 34: 405-417.

33. Lefkowith JB. Cyclooxygenase-2 specificity and its clinical implications. Am J Med 1999; 106 (5B): 43S-50S.

34. Fort J. Celecoxib, a COX-2 specific inhibitor: the clinical data. American Journal of Orthopedics (supplement) 1999; 28 (35): 13-18.

35. Silverstein F, Simon L. Celecoxib is associated with a lower incidence of serious $\mathrm{Gl}$ toxicity relative to nonsteroidal anti-inflammatory drugs (NSAIDs): the celecoxib long-term arthritis safety study (CLASS). Program and Abstracts from the $64^{\text {th }}$ Annual Scientific Meeting of the American College of Rheumatology; October 29-November 2, 2000; Philadelphia, Pennsylvania. Abstract 1907.

36. Whelton A. The celecoxib long-term safety trial (CLASS): Cardiovascular safety of celecoxib is equivalent to nonsteroidal anti-inflammatory drugs (NSAIDs). Program and Abstracts from the $64^{\text {th }}$ Annual Scientific Meeting of the American College of Rheumatology; October 29November 2, 2000; Philadelphia, Pennsylvania. Abstract 1904. 